\title{
Microbial Profiling of Cultural Systems for Suppression of Phytophthora Root Rot in Fraser Fir
}

\author{
B. S. Richter, D. M. Benson, and K. L. Ivors, Department of Plant Pathology, North Carolina State University, Raleigh 27695
}

\begin{abstract}
Richter, B. S., Benson, D. M., and Ivors, K. L. 2011. Microbial profiling of cultural systems for suppression of Phytophthora root rot in Fraser fir. Plant Dis. 95:537-546.

Phytophthora root rot of Fraser fir, caused by several Phytophthora spp., is a severe problem in Christmas tree production. Since fungicides are not economically viable for disease management in field plantings and host resistance is not available, cultural control methods were investigated. Mulches, dairy compost, and soil $\mathrm{pH}$ adjustment were tested at five field sites in North Carolina. Treatments included wood chips, wood chips plus compost, or pine bark as raised beds, and compost or sulfur tilled into soil. Soil and mulch microbial populations were characterized by dilution plating and calculation of a log series

after planting. Bacterial and fungal counts, microbial activity, and cellulase activity were higher in mulch than in soil at all sites and times $(P<0.01)$, and generally did not differ among mulch types or among soils. Treatments significantly affected disease ratings and tree survival at three of five sites, with one or more mulch treatments yielding lower disease ratings and greater survival than controls. Tree mortality at each time point varied significantly with cellulase activity in the upper root zone $(P=0.005)$. Other biological variables did not show significant relationships with disease ratings or mortality.
\end{abstract} diversity index, and by enzyme analyses at 5, 12, 17, and 24 months
Phytophthora root rot, caused by Phytophthora cinnamomi Rands and other species, is the primary limiting disease in production of Fraser fir (Abies fraseri (Pursh) Poir) for the fresh cut Christmas tree market in western North Carolina. Phytophthora root rot is a problem in every stage of production, and can kill trees of all ages. P. cinnamomi is frequently introduced into fields on infested transplants; one survey recovered the pathogen from $1.2 \%$ of asymptomatic transplants sampled from nursery transplant beds (7). In field plantings, disease development is associated with poorly drained areas (25), and once the pathogen becomes established in a conducive site, mortality may progress over time, rendering the site unfit for future production (8). In a 2006 North Carolina Christmas Tree Pest Management Survey, $72 \%$ of growers reported field mortality due to Phytophthora root rot, compared to $60 \%$ in a 2001 survey (J. Sidebottom, unpublished). While average disease incidence in individual production sites remained relatively stable at 9 to $10 \%$ from 1974 to $2000(7,25)$, these numbers do not reflect the loss of productivity due to abandonment of sites infested with Phytophthora.

Mefenoxam, fosetyl-Al, and a few less commonly utilized fungicides are registered for use in Fraser fir plantations; however, these fungistatic formulations are useful only to contain outbreaks and slow the spread of the disease, allowing for imminent harvest of surrounding trees. Long-term use of fungicides is not economically viable for this perennial crop, which is typically planted in a 7- to 9-year cycle, and is not effective enough to allow continued productivity of infested land. While some disease resistance has been identified among other fir species, it is not typically observed in Fraser fir, and is not currently available as a control option $(23,27,28)$. Although Phytophthora root rot has been cited as the number one pest problem by over $35 \%$ of growers surveyed, fewer than $2 \%$ reported using any fungicides (J. Sidebottom, unpublished). Affected areas are often left fallow, or planted in more resistant but less profitable species. Alternative methods are needed

Corresponding author: B. S. Richter, E-mail: brantlee_richter@ncsu.edu

Accepted for publication 7 December 2010.

doi:10.1094/PDIS-03-10-0238

(C) 2011 The American Phytopathological Society to allow continued production of Fraser fir, which has the highest customer demand among fresh-cut Christmas tree species (57).

Current cultural control recommendations are based on avoidance strategies such as selection of transplant stock and nursery irrigation source, placement of seed and transplant beds to minimize periods of high soil moisture, and avoidance of high-risk field sites, which are characterized by their propensity to experience standing or running water during rainfall events. There are currently no cultural recommendations available for managing a site after Phytophthora has been introduced. This research was conducted to evaluate mulch-based cultural systems for managing Phytophthora root rot under natural disease pressure. The approach was based on the "Ashburner system" developed for avocado production in Australia and California $(10,14,19)$ which utilizes fresh woody mulches in combination with animal manures and/or fertilizers to create a pathogen-free zone in which feeder roots may develop. Disease reduction has been associated with the presence of inhibitory biota and enzyme activity within the mulch $(10,18,58)$. Although roots extending into underlying soil are vulnerable to infection, those produced within the mulch avoid infection and allow the tree to remain productive. Combining this system with development of resistant root stocks has allowed continued production of avocados on Phytophthora-infested land, and shows promise for adaptation to Fraser fir production systems.

In addition to mulch-based cultural options, soil $\mathrm{pH}$ management may be an option for reducing Phytophthora root rot disease pressure. Optimal $\mathrm{pH}$ for development of Phytophthora root rot on avocado was identified at approximately 6.5 , with less disease at both low (3.5 to 5) and high $(\geq 8) \mathrm{pH}(60)$. In a survey of Hawaiian soils, Ko and Shiroma (33) found that suppression of chlamydospore germination in $P$. cinnamomi occurred more frequently in soils with $\mathrm{pH}$ near 4 or 8 than in soils with $\mathrm{pH}$ near 6 , and inhibition of sporangium formation has also been observed in peat-based mix and pine bark at $\mathrm{pH}<4(6,9)$. Reduction of soil $\mathrm{pH}$ has shown mixed results as a control for Phytophthora root rot, with successful disease reduction in field-planted pineapple (42) and containergrown rhododendron (9), but unsuccessful results in nursery and field-grown avocado (60). While low $\mathrm{pH}$ may directly inhibit $P$. cinnamomi in soil, it may also disrupt potentially suppressive microbial communities as well as affecting micronutrient uptake. Fraser fir is native to high elevation mountain soils with $\mathrm{pH} 3.5$ to 4.2 , but production sites are typically limed to maintain $\mathrm{pH}$ at or 
above 5.5 (5). Because Fraser fir is naturally adapted to low $\mathrm{pH}$, reduction of soil $\mathrm{pH}$ to a range inhibitory to $P$. cinnamomi may also be a viable cultural control strategy.

This study examined three mulch types and two soil treatments in naturally infested field plantations of Fraser fir for their effects on Phytophthora root rot development. In addition to monitoring disease progress, we also examined aspects of the soil and mulch microbial communities which have previously been associated with successful mulching systems, in order to determine whether these microbial measures could be consistently correlated with disease suppression. Correlations with specific microbial parameters could provide both a means of predicting disease suppressive potential in mulches and a basis for enhancement of disease suppression in future mulch-based cultural systems. Our objectives were to (i) evaluate the efficacy of mulches, dairy compost, and soil $\mathrm{pH}$ adjustment for reducing Phytophthora root rot disease in the field; (ii) track changes in microbial numbers, activity, and cellulase production over time in mulches and treated soils; and (iii) examine the relationships between disease inhibition and microbial parameters across multiple field sites.

\section{Materials and Methods}

Field study. Field trials were initiated in the spring of 2006 at five sites located within established Fraser fir plantations in Mitchell, Avery, and Watauga counties in western North Carolina, and Grayson County, Virginia (Fig. 1). All sites had a history of Phytophthora root rot within the study areas, with $P$. cinnamomi isolated from soil or symptomatic trees in previous plantings. Soil samples were collected from each site prior to study establishment and analyzed for basic soil chemistry (Humic matter, CEC, base saturation, $\mathrm{pH}, \mathrm{P}, \mathrm{K}, \mathrm{Ca}, \mathrm{Mg}, \mathrm{Mn}, \mathrm{Al}, \mathrm{Zn}, \mathrm{Cu}$, and $\mathrm{S}$ ) by the North Carolina Department of Agriculture Agronomic Services lab (Table 1). Rainfall data were collected for each site throughout the duration of the study, using a tipping bucket collector with a data logger.

Each site contained four treatments plus one nonamended control, arranged in a randomized complete block design. Field treatments included wood chip mulch (WC), compost-amended wood chip mulch (WCC), or pine bark (PB) applied on top of existing

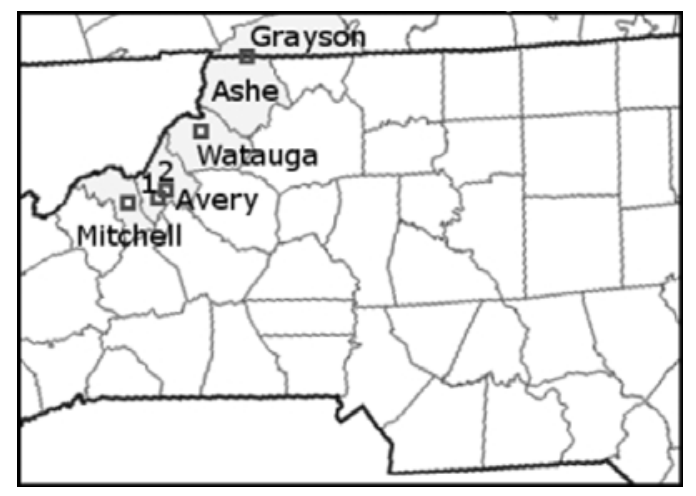

Fig. 1. Site map, showing locations of five field trials conducted on commercial production sites for Fraser fir in Mitchell County, Avery County, Watauga County, and Ashe County, NC, and Grayson County, VA. soil in rows as "raised beds," and compost or soil sulfur incorporated into the soil in rows by rototiller. The compost, wood chip, and compost-amended wood chip treatments were applied at all sites; the remaining treatments were divided to include pine bark beds at three sites and sulfur incorporation at two sites. Each treatment consisted of five replicate plots of 16 trees (four by four) per plot, for a total of 80 trees per treatment and 400 trees per site, with the exception of one site, Avery-2, which contained only four replicates due to space constrictions. Trees were planted on a standard $152-\mathrm{cm}$ grid with an unplanted buffer strip between treatment blocks. All mulch materials were fresh-milled and delivered to each site within 5 weeks before planting. Wood chips for all sites were white pine, chipped with bark attached. Two local suppliers were used to minimize transport distances. Chips used at the Mitchell and Avery county sites were mixed length (most chips less than $10 \mathrm{~cm}$ ) and approximately 5 to $10 \mathrm{~mm}$ thick. Chips used at the Watauga and Grayson county sites were a mixture of mixedlength chips and fine shavings. Pine bark (Avery-1, Mitchell, and Watauga sites) was a shredded product, rather than chipped, consisting primarily of longer bark strips $(10 \mathrm{~cm}$ or greater) with minimal wood attached. The compost used at all sites was a bagged dairy manure compost (Daddy Pete's Plant Pleaser, Stony Point, NC). Mulch beds were constructed by applying a layer of material approximately $30 \mathrm{~cm}$ deep to a $58 \mathrm{~m}^{2}$ plot $(7.62 \times 7.62 \mathrm{~m})$, and then removing material down to the soil surface to create four bed rows with three $30-\mathrm{cm}$-wide aisles aligned parallel to the predominant slope direction. For the WCC treatments, bagged composted dairy manure was blended into wood chip beds on site with a rototiller at a rate of $15 \%$ compost, by volume. An equivalent volume of compost was tilled into soil for the compost-amended soil treatment. Sulfur was incorporated into soil at a rate of $1.09 \mathrm{~kg}$ per row of four trees; this rate was calculated to reduce soil $\mathrm{pH}$ within the root zone to a target of approximately $\mathrm{pH} 3.5$ to 4 .

Because asymptomatic infected transplants are often unknowingly sold in the commercial market, the possibility of conducting field trials using transplants already infected with Phytophthora presented a potential confounding factor. Trees used in this study were purchased from three suppliers, in order to minimize the likelihood that an infestation in a single lot would affect all study sites. The Mitchell and Avery- 1 sites received plug +1 seedlings (greenhouse-produced plugs, grown for 1 year in a field transplant bed) from a nursery in Sublimity, OR, the Grayson and Watauga sites received 2-2 seedlings (grown for 2 years in a seed bed, plus 2 additional years in a transplant bed) from a nursery in Spartanburg, PA, and the Avery-2 site received 3-0 seedlings (grown for 3 years in a seed bed) from a tree farm in Salem, OR. Seedlings were hand-planted; in mulch treatments, seedlings were placed with the crowns above the soil line to encourage root growth within the mulch. Plots were maintained by growers using standard commercial practices, to include fertilization, weed control, and tree shearing. Chemical mowing (low rates of glyphosate) was used for weed control, with some additional mowing and handweeding performed during plot assessments. At 12 months after planting, additional fertilizer (18-46-0 diammonium phosphate, 1.7 $\mathrm{kg}$ per plot) was applied at all sites using a broadcast spreader. Bed height measurements were conducted on all sample dates to monitor settling rates and mulch loss.

Table 1. Selected soil chemistry values for the five study sites before treatment applications ${ }^{\mathrm{x}}$

\begin{tabular}{|c|c|c|c|c|c|c|c|c|c|c|c|}
\hline Site & $\begin{array}{c}\text { Humic } \\
\text { matter }(\%)\end{array}$ & CEC & $\begin{array}{l}\text { BS }^{y} \\
(\%)\end{array}$ & pH & $\begin{array}{c}\mathbf{P} \\
(\mathbf{p p m})\end{array}$ & $\underset{(\mathbf{p p m})}{\mathbf{K}}$ & $\begin{array}{c}\text { Ca } \\
(\%)^{\mathrm{z}}\end{array}$ & $\begin{array}{l}\text { Mg } \\
(\%)^{\mathrm{z}}\end{array}$ & $\underset{(\mathbf{p p m})}{\mathrm{Mn}}$ & $\underset{(\mathbf{p p m})}{\mathrm{Cu}}$ & $\begin{array}{c}\mathbf{S} \\
(\mathbf{p p m})\end{array}$ \\
\hline Mitchell & 0.36 & 6.7 & 89 & 5.6 & 108.0 & 314.8 & 68 & 15 & 102.5 & 0.70 & 8.22 \\
\hline Avery-1 & 0.71 & 12.6 & 86 & 5.2 & 198.6 & 469.2 & 64 & 13 & 35.7 & 1.2 & 2.12 \\
\hline Avery-2 & 1.28 & 12.8 & 86 & 5.4 & 6.0 & 285.4 & 54 & 26 & 14.5 & 1.0 & 1.56 \\
\hline Watauga & 1.11 & 12.9 & 84 & 5.0 & 122.4 & 268.8 & 61 & 17 & 87.8 & 25.6 & 1.94 \\
\hline Grayson & 0.91 & 12.5 & 81 & 4.8 & 281.4 & 382.2 & 49 & 24 & 32.5 & 0.97 & 1.96 \\
\hline
\end{tabular}

${ }^{x}$ Values are averages of two samples from each site. Analyses performed by the NC State Agronomic Lab, Raleigh, NC.

y Base saturation.

z Percentage of cation exchange capacity (CEC) occupied by nutrient listed. 
Disease assessments were conducted at the beginning and end of each growing season (May and September) through the first 2 years at all sites. Disease severity was rated on a 4-point scale, on which 1 was apparently healthy foliage, 2 was showing significant chlorosis, 3 was showing wilting, flagging, severe chlorosis, and/or branch necrosis, and 4 was dead. Survival within each plot (16 plants) was calculated from ratings data by assigning a status of 1 to ratings 1 to 3 , and of 0 to plants with a rating of 4 , and then calculating mean survival status. Four months after planting, root samples were collected from symptomatic trees (nine samples at Avery-1, eight at Avery-2, eight at Mitchell, and five at Watauga) and plated on PARPH-V8 agar (22) for confirmation of Phytophthora infection. Phytophthora was recovered from 26 of 30 root samples $(87 \%)$, a rate consistent with expected recovery in culture from known infected samples $(29,35,39,53)$. At the end of the second growing season, roots were collected from one currentseason mortality in each plot (as available) at all sites, and samples were tested for Phytophthora using an ELISA test kit (Phytophthora PathoScreen Kit, Agdia, Inc., Elkhart, IN) following manufacturer instructions and using $0.4 \mathrm{~g}$ of root material for each analysis. Out of 85 samples tested, 77 (91\%) yielded positive ELISA results. Results from immuno-assay kits are known to vary by host and sample type $(41,53)$, and no information is available on expected rates of detection from infected fir root tissue with this test method. For our analysis, roots from all samples with negative results and from five ELISA-positive samples were cultured on PARPH-V8, and Phytophthora was recovered from all positive and no negative samples. However, studies with $P$. ramorum in leaf tissue showed a false negative rate of $29 \%$ for this ELISA test kit and $56 \%$ for culturing, as compared with detection using nested PCR (12), indicating that a $91 \%$ recovery rate may be taken as acceptable confirmation of Phytophthora infection in the symptomatic plants.

Because Phytophthora root rot produces a distinctive symptom progression in Fraser fir, and other root rot diseases are very rare in North Carolina Fraser fir plantations, all mortality among trees showing typical symptom progression was presumed to be Phytophthora root rot related, after initial confirmatory testing on a subsample of mortalities. Other root rot diseases which have occasionally been reported within the region are Armillaria and annosum root rots $(15,21,24)$; no signs of these diseases were observed on or near any of the mortalities in this study, nor were any occurrences reported on Fraser fir by the North Carolina State University Plant Disease and Insect Clinic during the study period. Clinic records from 1999 through 2006 show 212 diagnoses of Phytophthora root rot in Fraser fir, but none of either Armillaria or annosum root rot, and no other pests, diseases, or abiotic disorders have been identified within the growing region with symptoms similar to those produced by Phytophthora root rot.

Soil and mulch samples for biological analyses and $\mathrm{pH}$ monitoring were collected at three of the five sites: Avery-1, Watauga, and Grayson. Plots were sampled at three levels: upper mulch (top half of the mulch profile), lower mulch (bottom half of the mulch profile), and soil (0 to $15 \mathrm{~cm}$ depth). Samples were collected $30 \mathrm{~cm}$ out from the base of each of the four interior trees in a plot, and the samples from each level were bulked for analysis. The sample point for each tree was rotated by compass direction for each sampling date. During the second season, plant tissue samples were also collected from each plot in order to determine effects of treatments on plant nutrient status. At the end of the third growing season, a small subset of plants at the Avery-1 site was selected for destructive sampling, to include two living and two dead plants from each treatment. All roots were removed and sorted by layer, then quantified by dry weight, and by image analysis for root length using APS Assess software (Version 2.0, APS Press, St. Paul, MN). For each sample (plant $\times$ layer), $501-\mathrm{cm}$ segments were plated on PARPH-V8 agar (22) for detection of Phytophthora, and the proportion of positive segments was calculated. If the sample consisted of less than $50 \mathrm{~cm}$ of total root length, the entire sample was divided into $1-\mathrm{cm}$ segments and plated.
Biological analyses. Soils and amendments collected at each sample date were processed for enumeration and diversity of culturable bacteria, fungi, and cellulose-degrading microorganisms, and for total microbial activity and cellulase enzyme activity. Sample $\mathrm{pH}\left(1: 2\right.$ slurry by volume in $\left.0.01 \mathrm{M} \mathrm{CaCl}_{2}\right)$ was also recorded for every sample analyzed. Analysis of culturable organisms was performed by dilution plating on R2A (Difco) for bacteria, modified rose bengal for fungi (47), and cellulose medium for cellulose degraders (3). Three subsamples were drawn from each bulked sample, diluted in log-series, and plated in a 3-log range for each media type. After counts were obtained, 50 colonies were selected from one plate per subsample by counting across the media from an arbitrarily designated point on the plate edge, and these were used to obtain sample richness based on colony morphology. Diversity was calculated using a log series index (26,37). Smaller sets were used when 50 distinct colonies were not available; because the log series index is a poor predictor of diversity with very small sample size (26), samples with fewer than 30 colonies were omitted from analysis. Results from three subsamples were averaged for each plot at each layer.

Samples were analyzed for total microbial activity by fluorescein diacetate hydrolysis (FDA) (1). Samples were incubated with $30.2 \mu \mathrm{g} / \mathrm{ml}$ fluorescein at $30^{\circ} \mathrm{C}$ for $10 \mathrm{~min}$, shaken briefly, and incubated an additional $10 \mathrm{~min}$. Samples were again shaken, and a 5-ml aliquot was transferred to $5 \mathrm{ml}$ of 2:1 chloroform/methanol solution to stop the reaction. After centrifugation, the aqueous fractions were filtered into spectrophotometer tubes, and absorbance was read at $490 \mathrm{~nm}$. Four subsamples and one substrate negative control were processed for each sample point at each layer.

Cellulase activity was assessed by a modified Schinner and von Mersi method $(46,54)$. Samples were incubated at $37^{\circ} \mathrm{C}$ for $24 \mathrm{~h}$ in $0.35 \% \mathrm{wt} / \mathrm{vol}$ carboxymethyl cellulose in acetate buffer, then transferred to microcentrifuge tubes and centrifuged for $3 \mathrm{~min}$. Supernatants were diluted and processed for photometric analysis of reducing sugars. Three subsamples and one substrate negative control were processed for each sample point at each layer.

Soil baiting and pathogen quantification by sieving and plating on selective medium were conducted on samples collected during the first season $(22,30,44)$, but detection levels were insufficient for resolution of pathogen populations, hence these analyses were discontinued.

Statistical analyses. SAS software (Version 9.1, SAS Institute, Cary, NC) was used for all statistical analyses. To discern treatment and time effects for all biological data sets, repeated measures analysis of variance was conducted using a linear mixed model, with the SLICE option used to slice data sets by time and by treatment and Tukey's adjustment applied for least squares means separations. For determination of the covariance structure for each data set, analysis was repeated with each of 11 different models for covariance structure; the structure which resulted in the lowest value for the Akaike Information Criterion (AIC) was selected. Mixed model repeated measures analysis was also used with biological variables as covariates to determine relationships between biological parameters and disease progress, expressed as change in survival for each block at each time period. For this analysis, data from all sites were used, with site as a random variable, and only the four treatments common to all sites were included. Correlation analysis was also used to detect correlations among biological data. Area under the disease progress curve (AUDPC) values were calculated for both disease rating and survival data; these were compared by analysis of variance using the general linear model (GLM) procedure in SAS. Ratings and survival at the conclusion of the 24-month study period were also examined using Friedman's nonparametric analysis, and Dunn's procedure for all pairwise comparisons was performed using the \%DUNN macro (31). The GLM was used for analysis of variance on nutrient data, and the Kruskal-Wallis nonparametric analysis for root infection data. Data transformations were applied where deviations from normality could be reduced. An alpha level of $\alpha=0.05$ was used for all tests. 


\section{Results}

Plant disease data. Tree mortality at 2 years after planting ranged from 13 to $70 \%$, with a mean mortality of $31 \%$ in mulched and $48 \%$ in nonmulched plots. Comparison of AUDPC (Fig. 2 and

\section{Field Mortality of Fraser Fir}
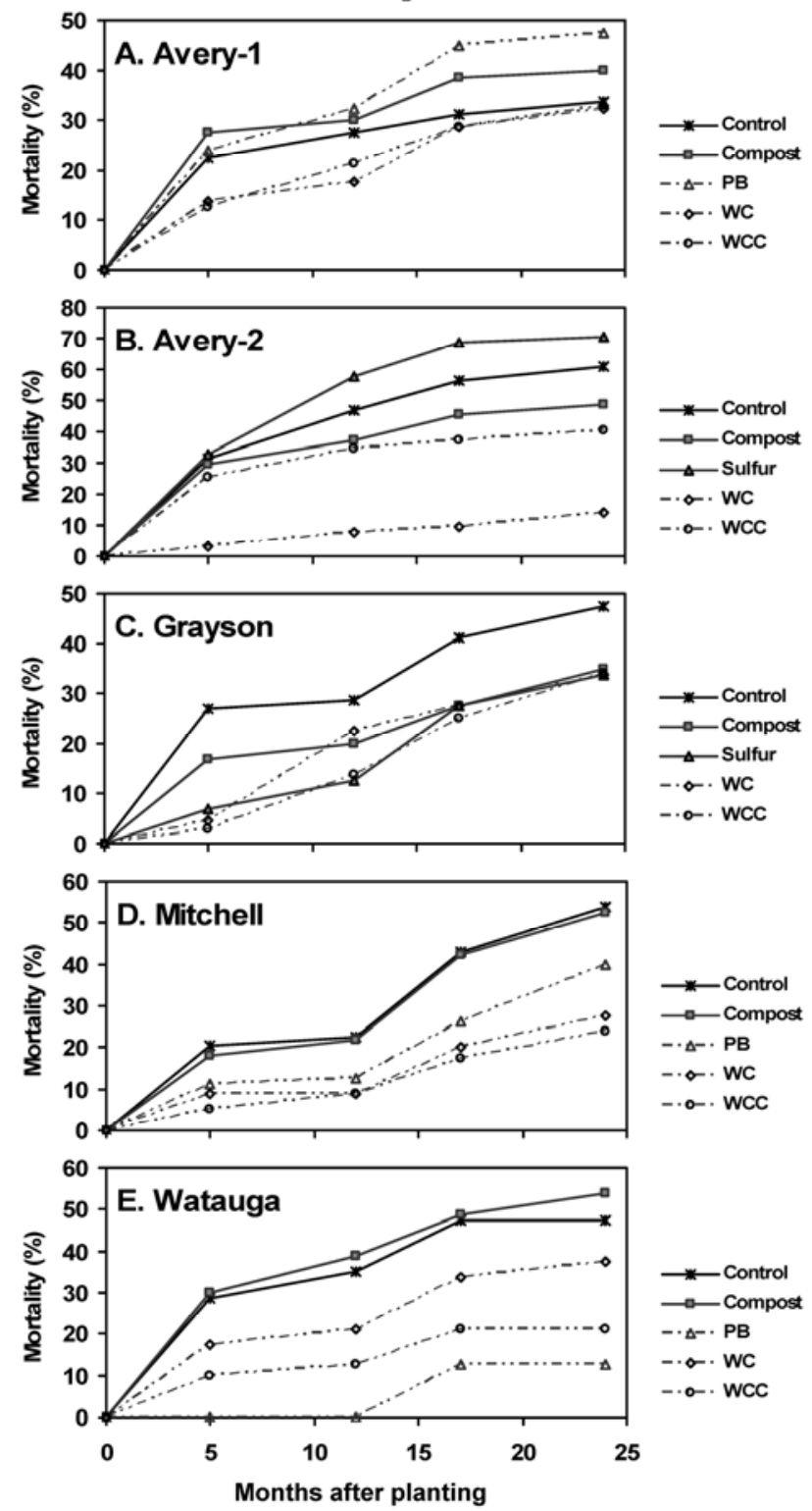

Fig. 2. Disease progress curves from five Fraser fir production sites (A to $E$ ), with mortality due to Phytophthora root rot expressed as percentage of trees deceased at each of four sample dates. Differences in area under the curve were significant only at the Avery-2 site $(P=0.053)$. $P B=$ pine bark, $W C=$ wood chip, $W C C=$ wood chip with compost.
Table 2) using the general linear model showed significant treatment effects at only one site each for mortality (Avery-2, $P=$ 0.053 ) and disease ratings (Watauga, $P=0.036$ ). Analysis of final disease ratings and mortality using Friedman's nonparametric analysis yielded clearer separation among treatments, with significant treatment effects $(P<0.001)$ at three sites (Mitchell, Avery-2, and Watauga) for both mortality and disease ratings. At the Mitchell site, trees in WCC mulch had significantly better survival (24\% mortality) and less disease development than control and compost-treated soil (54, 53\% mortality), and WC mulch treatment also significantly reduced mortality $(28 \%)$ relative to control soil. At the Watauga site, PB and WCC had lower mortality $(13,21 \%)$ than control and compost-treated soil (48, 54\% mortality), WCC had lower ratings than compost-treated soil, and trees in PB had lower ratings than control or compost-treated soil, or those in WC mulch. At the Avery-2 site, trees in WC mulch had lower disease ratings and mortality (14\%) than all nonmulch treatments (48 to $70 \%$ mortality) and lower ratings than WCC mulch; trees in sulfurtreated soil also had higher mortality $(70 \%)$ than trees in WCC mulch $(41 \%)$.

Tree mortality at each time point, measured as change in survival since previous sample date, covaried significantly with cellulase activity in the upper portion of the root zone $(P=0.005)$. Covariance between tree mortality and FDA was not significant at the 0.05 level $(P=0.121)$. Neither cellulase nor FDA levels among soils showed significant covariance with tree survival.

Within the small subset of trees sampled for root distribution at the Avery-1 site, P. cinnamomi was recovered from $100 \%$ of mortalities, and from $30 \%$ of living trees examined. Treatment did not significantly affect percentage of roots from which Phytophthora was recovered $(P=0.214)$. Within mulched treatments, infected roots were found in both soil and mulch layers. Though recovery of Phytophthora tended to be lower among root samples from mulch layers (12\%) than from underlying soil (20\%), differences were not significant $(P=0.114)$. Among mulch-planted trees, living trees showed higher mean proportions of root length within mulch than dead trees for all three mulch types, but the relationship between mortality status and percentage of root system in mulch was not significant, by length or dry mass $(P=0.423)$. There was a significant difference detected among mulch types in proportion of root length within mulch $(P=0.039)$; WC and WCC mulches had similar proportions of root length in mulch, which were approximately eight times those found in PB mulch (Table 3).

Biological data. Results from all of the biological analyses conducted for the three sampled sites (plate counts, FDA, and cellulase activity) were positively and significantly correlated to one another, and to sample moisture content (Table 4). FDA and cellulase activity were more strongly correlated with one another $(r=0.545)$ than with colony forming units detected on any media type, and were more strongly correlated with moisture $(r=0.638,0.777)$ than with any biological variable. Enumerations on cellulose agar showed the weakest correlation with all other variables with the exception of bacterial enumeration, with which it correlated well $(r$ $=0.469$ ).

Microbial enumerations and diversity. Bacterial and fungal counts were significantly higher in mulch than in soil at all sites

Table 2. Area under the disease progress curve for Fraser fir mortality at five sites ${ }^{\mathrm{Z}}$

\begin{tabular}{lccccccc}
\hline & & \multicolumn{5}{c}{ Treatment } \\
\cline { 3 - 7 } Site & $\boldsymbol{P}$ value & Control & Compost & Sulfur & WC & WCC & PB \\
\hline Mitchell & 0.079 & 7.032 & 6.763 & - & 3.213 & 2.706 & 4.400 \\
Avery-1 & 0.151 & 6.056 & 7.175 & - & 4.738 & 4.902 & 7.738 \\
Avery-2 & 0.053 & $10.195 \mathrm{ab}$ & $8.445 \mathrm{ab}$ & $12.023 \mathrm{~b}$ & $1.714 \mathrm{a}$ & $7.258 \mathrm{ab}$ & - \\
Watauga & 0.106 & 8.338 & 8.931 & - & 5.663 & 3.369 & 1.188 \\
Grayson & 0.701 & 7.478 & 5.075 & 3.998 & 4.446 & 3.686 & - \\
\hline
\end{tabular}

${ }^{\mathrm{z}}$ Values are calculated areas under disease progress curves, based on percent mortality in each treatment (mortality/month); values followed by the same letter within a row do not differ significantly from one another $(\alpha=0.05) . P$ values shown are from a general linear model analysis on natural log transformed data. Treatments included nonamended control plots, soil amendment with compost, and wood chip (WC) or wood chip with compost (WCC) mulch as raised beds at all sites; two sites included soil amendment with sulfur, and three sites included pine bark (PB) mulch beds. 
and sample times ( $P<0.01$, Fig. 3$)$. Over the duration of the study, bacterial counts from soil samples ranged from $1.3 \times 10^{7}$ to $2.2 \times$ $10^{8}$, while those from mulch ranged from $9.1 \times 10^{6}$ to $2.7 \times 10^{9}$. Fungal counts ranged from $9.8 \times 10^{4}$ to $1.2 \times 10^{6}$ among soils and from $6.2 \times 10^{4}$ to $2.8 \times 10^{7}$ in mulches. Cellulose degrader counts were more variable, with no significant difference between soil and mulch at the Grayson site, significantly higher counts in mulch at a single time point at the Watauga site, and at three of four sample dates at the Avery-1 site. Colony diversity was higher in soil than in mulch for cultured fungi and bacteria at all sites $(P<0.01$ at each site), and for cellulose-degraders at two of three sites (Avery1 and Grayson, $P<0.01$; Watauga, $P=0.554$ ). Among soils, bacterial and fungal counts varied by treatment and over time at all sites. Bacteria in soil tended to show seasonal fluctuations, with higher counts at the spring sample dates. Although not always statistically significant, sulfur-treated soil (Grayson site) consistently had higher fungal counts and lower fungal and bacterial diversity than other soils. Cellulose-degrader counts in soils varied significantly by treatment only at one site, at two of four sample times (Grayson at 12 and 24 months, $P=0.002$ at both times), but counts varied over time at all sites $(P<0.01)$.

Among the three mulch types, bacterial counts differed significantly at all sites through the first year $(P<0.05$ at each of three sites and two sample dates), with highest counts from WCC mulch. Differences were less consistent during the second year, with significant differences at both time points at Grayson, neither time point at Avery-1, and only the spring time point at Watauga. Bacterial counts within mulch differed significantly over time in all mulch types at all sites, with the single exception of WCC mulch at the Watauga site, but patterns over time were less consistent in mulch than in soil. Fungal counts in mulches differed by mulch type at only one site (Avery-1), where lower counts were observed in PB than the other two mulches at all time points. Fungal counts changed significantly over time only in the WC mulch at two of three sites (Avery-1 and Grayson, $P=0.005,0.001$ ). Cellulosedegrader counts differed by mulch type at all sites; one of these sites (Grayson) showed differences at every time point, and the other two sites at only two of four sample dates, each. Among the mulch types, WCC generally yielded the highest cellulose-degrader counts across sites and over time. Counts changed over time only at the Avery-1 site in the PB and WC mulches. Differences in bacterial colony diversity were observed among mulch types at the Grayson site at three of four time points, but only at one (Avery-1) or two (Watauga) time points at the other sites. Where these differences occurred, WCC mulch had higher diversity than one or both of the other mulch types. Fungal colony diversity did not differ among mulch types, with the exception of two time points at a single site (Avery-1), where PB showed higher diversity than WC and WCC mulches. Cellulose-degrader diversity generally did not differ among mulch types.

Bacterial counts differed between upper and lower mulch layers at two of three sites, and fungal and cellulose-degrader counts at one site each. These differences did not appear to be related to season or rainfall, but complete analysis of weather factors was not conducted.

Total microbial activity. Microbial activity (fluorescein diacetate hydrolysis) was significantly higher in mulch than in soil at all three sites and all four sampling dates $(P<0.001$, Fig. 4). Comparisons among soils differed across sites. At the Avery-1 site, soil activity did not vary significantly by treatment or over time. At the Watauga site, microbial activity varied by treatment at both of the spring samplings (12 and 24 months, $P=0.003,0.043$ ), but not at the fall sampling times (5 and 17 months), and activity in all treatments varied over time $(P<0.001)$. At the Grayson site, soil activity varied by treatment through the first, but not the second, year $(P$ $=0.045,0.010$ at 5 and 12 months), and activity varied over time in soil under mulch $(P=0.011,0.002$ under WC, WCC $)$, but not in the control, sulfur or compost-treated soil.

Table 3. Root distribution of Fraser fir in soil and mulch layers at an Avery County production site ${ }^{\mathrm{z}}$

\begin{tabular}{|c|c|c|c|c|c|c|}
\hline \multirow[b]{2}{*}{ Treatment } & \multicolumn{3}{|c|}{ Root length (cm) } & \multicolumn{3}{|c|}{ Root mass (g, dry) } \\
\hline & Upper & Lower & Soil & Upper & Lower & Soil \\
\hline \multicolumn{7}{|l|}{ Living trees } \\
\hline PB mulch & 0 & 354.8 & $7,664.5$ & 0 & 1.360 & 47.326 \\
\hline WC mulch & 90.1 & $2,894.9$ & $5,499.9$ & 0.089 & 7.055 & 28.370 \\
\hline WCC mulch & 556.0 & $1,560.8$ & $4,229.5$ & 1.459 & 5.202 & 26.749 \\
\hline \multicolumn{7}{|l|}{ Dead trees } \\
\hline PB mulch & 0 & 66.4 & $2,835.3$ & 0 & 0.827 & 25.3435 \\
\hline WC mulch & 4.5 & $1,050.1$ & $2,162.1$ & 0.002 & 1.758 & 22.157 \\
\hline WCC mulch & 0 & 653.8 & $2,042.9$ & 0 & 4.191 & 14.200 \\
\hline
\end{tabular}

${ }^{\mathrm{z}} \mathrm{PB}=$ pine bark, $\mathrm{WC}=$ wood chip, $\mathrm{WCC}=$ wood chip with $15 \%$ dairy compost, by volume. Roots of two living and two dead plants from each treatment were excavated sequentially from the upper half of the mulch, the lower half of the mulch, and the underlying soil. Length was assessed using APS Assess software (Version 2.0, APS Press), and mass is reported as weight after drying at $80^{\circ} \mathrm{C}$ for $48 \mathrm{~h}$. Numbers reported are averaged from two living or dead trees per treatment. The proportion of root length found within mulch layers varied significantly $(P=0.039)$, with more roots found in WC and WCC mulch than in PB mulch.

Table 4. Correlation among biological variables from soil and mulch samples ${ }^{\mathrm{z}}$

\begin{tabular}{|c|c|c|c|c|c|c|}
\hline & $\begin{array}{c}\text { Moisture } \\
(\%)\end{array}$ & $\begin{array}{c}\text { CEL } \\
\text { (CFU) }\end{array}$ & $\begin{array}{c}\text { RB } \\
(\mathbf{C F U})\end{array}$ & $\begin{array}{c}\text { R2A } \\
\text { (CFU) }\end{array}$ & $\underset{\mu \mathrm{g} \mathrm{GE} \mathrm{g}^{-1}}{\text { CEA }}$ & $\underset{\mu \mathrm{g} \cdot \mathrm{g}^{-1} \mathbf{h}^{-1}}{\text { FDA }}$ \\
\hline Moisture & 1.000 & - & - & - & - & - \\
\hline CEL & $\begin{array}{l}0.1466 \\
0.0003\end{array}$ & 1.000 & - & - & - & - \\
\hline $\mathrm{RB}$ & $\begin{array}{c}0.3203 \\
<0.0001\end{array}$ & $\begin{array}{c}0.1902 \\
<0.0001\end{array}$ & 1.000 & - & - & - \\
\hline R2A & $\begin{array}{c}0.3993 \\
<0.0001\end{array}$ & $\begin{array}{c}0.4369 \\
<0.0001\end{array}$ & $\begin{array}{c}0.4694 \\
<0.0001\end{array}$ & 1.000 & - & - \\
\hline CEA & $\begin{array}{c}0.7772 \\
<0.0001\end{array}$ & $\begin{array}{l}0.1099 \\
0.0067\end{array}$ & $\begin{array}{c}0.2358 \\
<0.0001\end{array}$ & $\begin{array}{c}0.2637 \\
<0.0001\end{array}$ & 1.000 & - \\
\hline FDA & $\begin{array}{c}0.6378 \\
<0.0001\end{array}$ & $\begin{array}{c}0.1727 \\
<0.0001\end{array}$ & $\begin{array}{c}0.4272 \\
<0.0001\end{array}$ & $\begin{array}{c}0.4671 \\
<0.0001\end{array}$ & $\begin{array}{c}0.5449 \\
<0.0001\end{array}$ & 1.000 \\
\hline
\end{tabular}

${ }^{\mathrm{z}}$ Headings indicate sample moisture, colony enumerations on three media types $(\mathrm{CEL}=$ cellulose-degraders, $\mathrm{RB}=$ fungi, and $\mathrm{R} 2 \mathrm{~A}=$ bacteria $)$, cellulase enzyme activity (CEA, glucose equivalents, GE, micrograms per gram dry sample), and fluorescein diacetate hydrolysis (FDA, micrograms per gram, per hour). The $P$ value is shown beneath the Pearson correlation coefficient $(r)$ in each cell. 
Microbial activity was generally similar among mulch types, with significant differences observed only during the second year at two of three sites (Avery-1 and Watauga, $P=0.002$ and $P=$ 0.011 at 17 months, $P=0.054$ and $P<0.003$ at 24 months), and with no mulch type consistently yielding higher activity across sites. Activity within mulches did vary significantly over time with the single exception of WCC mulch at the Avery- 1 site $(P<0.05$ for all mulch types at all sites, except $P=0.226$ for WCC at Avery1 ), generally increasing over the 2-year study period. Activity was different between upper and lower mulch layers only at the 12month time point, at two sites.

Cellulase enzyme activity. Cellulase activity was significantly higher in mulch than in soil at all sites and times $(P<0.001$, Fig. $5)$. Among soils, activity differed among treatments on only one or two sample dates at each site; where significant differences occurred, compost-amended soil consistently showed the highest activity. Activity did not change significantly over time in soils, with the exception of soil under WC mulch at two sites.

Cellulase activity did not differ among mulch types at any site or date. Differences in activity within mulch over time were discernable only in the WCC mulch at the Avery-1 site $(P=0.033)$. Cellulase activity also did not generally differ between upper and lower mulch layers; significant differences were observed between layers at only one or two sample dates at each site (17 months at Avery-1 and Grayson, $P=0.041,0.043 ; 5$ and 17 months at Watauga, $P=$ $0.047,0.052)$. While activity did not change significantly over time within lower mulch, it did vary significantly with time in upper mulch $(P<0.01$ at all sites $)$.

Abiotic data. Plant tissue samples collected 17 months after planting indicated that treatments significantly impacted tissue $\mathrm{N}$, $\mathrm{P}, \mathrm{K}, \mathrm{Mg}, \mathrm{Mn}$, and B $(P=0.007,0.003,<0.001,0.025,0.024$, and 0.005), but did not impact $\mathrm{Ca}, \mathrm{S}, \mathrm{Fe}, \mathrm{Zn}$, or $\mathrm{Cu}$ (Table 5). Trees in sulfur-amended plots had the highest tissue $\mathrm{N}$ and $\mathrm{Mn}$, and the lowest P, K, and B. WCC mulched trees had the highest tissue P and $\mathrm{K}$. Trees in mulch treatments did not generally vary significantly from control trees in nonamended soil, with the exceptions of K (WCC higher than controls), Mg (controls higher than WC and $\mathrm{PB}$ ), and $\mathrm{B}$ (WCC higher than controls).

Sample $\mathrm{pH}$ differed among treatments and over time at all three monitored sites, with a $\mathrm{pH}$ range of 4.1 to 6.8 in all nonsulfured soils, 3.6 to 6.8 in lower mulches, and 3.4 to 6.2 in upper mulches across the duration of the study. At the site that included a soil sulfur treatment, $\mathrm{pH}$ in sulfur-treated soil ranged from 3.1 to 4.3, with a single outlier of 5.1 at the third sample date. With the exception of that date, sulfur-treated soil had significantly lower $\mathrm{pH}$ than all other treatments. There was no significant covariation between either soil $\mathrm{pH}$ or $\mathrm{pH}$ in the upper portion of the root zone (soil or mulch) and tree survival within the four treatments common to all

\section{Bacterial Enumerations}
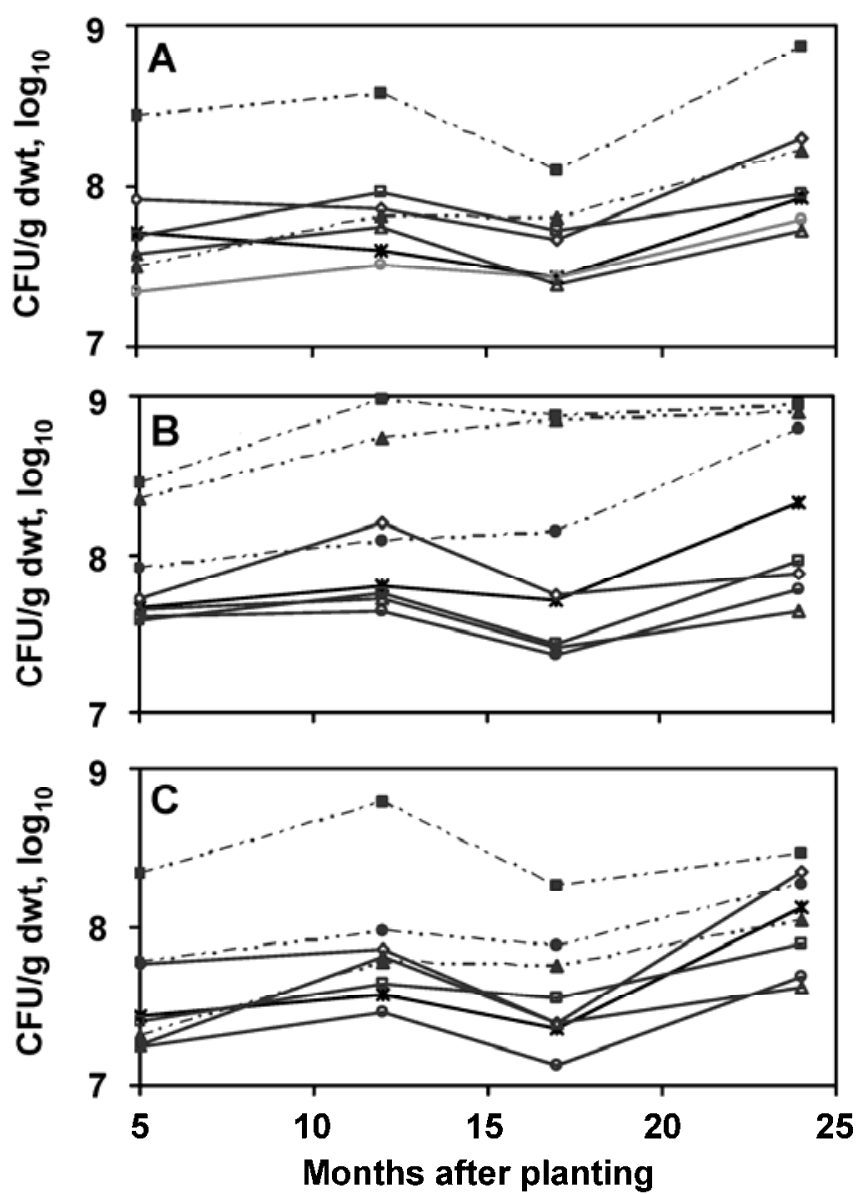

Fungal Enumerations
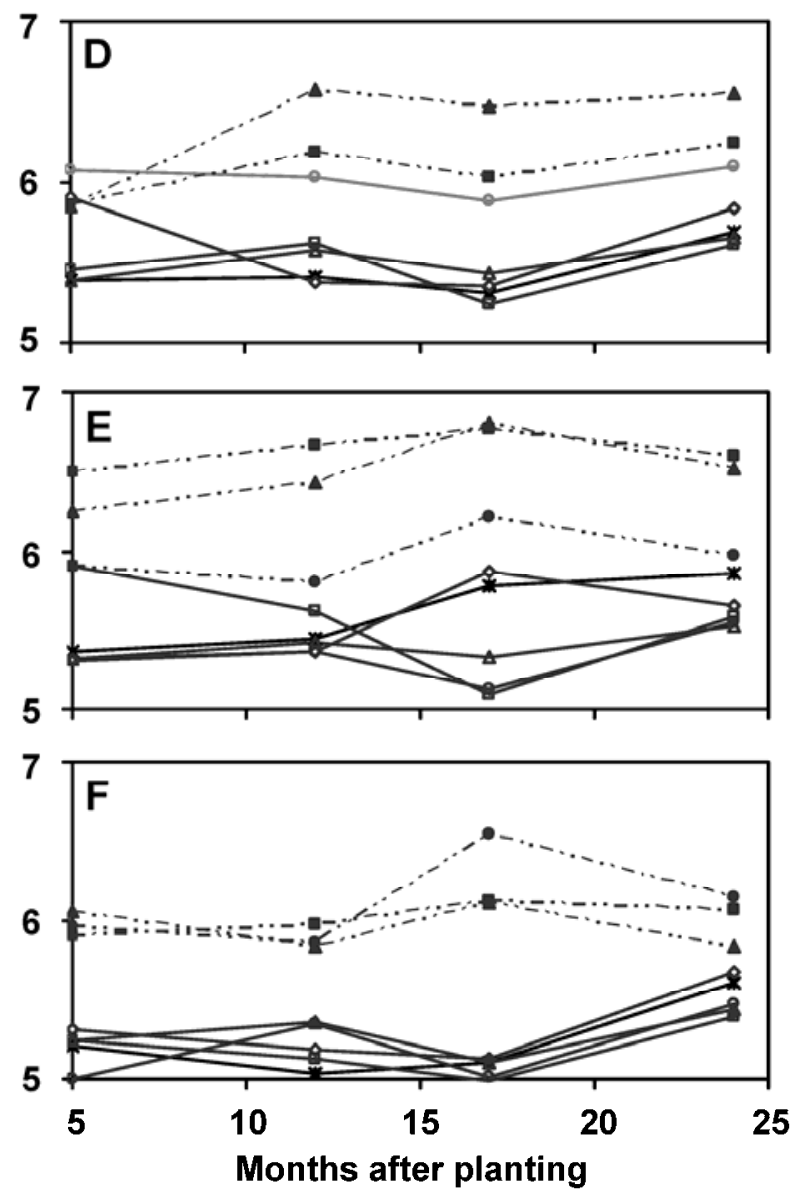

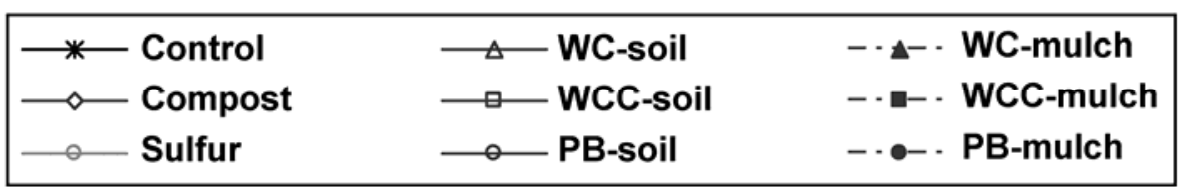

Fig. 3. Bacterial (A to $\mathbf{C}$ ) and fungal (D to F) enumerations in soil and mulch samples from three Fraser fir study sites (A and D, Grayson; B and E, Avery-1; C and F, Watauga). Counts are reported as colony forming units (CFU) per gram dry sample. Mulch beds were established at time of planting, and samples were taken at 5, 12, 17, and 24 months after planting. PB = pine bark, WC = wood chip, $W C C=$ wood chip with compost. 
three sites. There was also no significant covariation between $\mathrm{pH}$ and tree survival within the one site that included the sulfur treatment.

Both summer (May to September) and winter (September to May) rainfall during the first year were positively correlated with

\section{Total Microbial Activity}
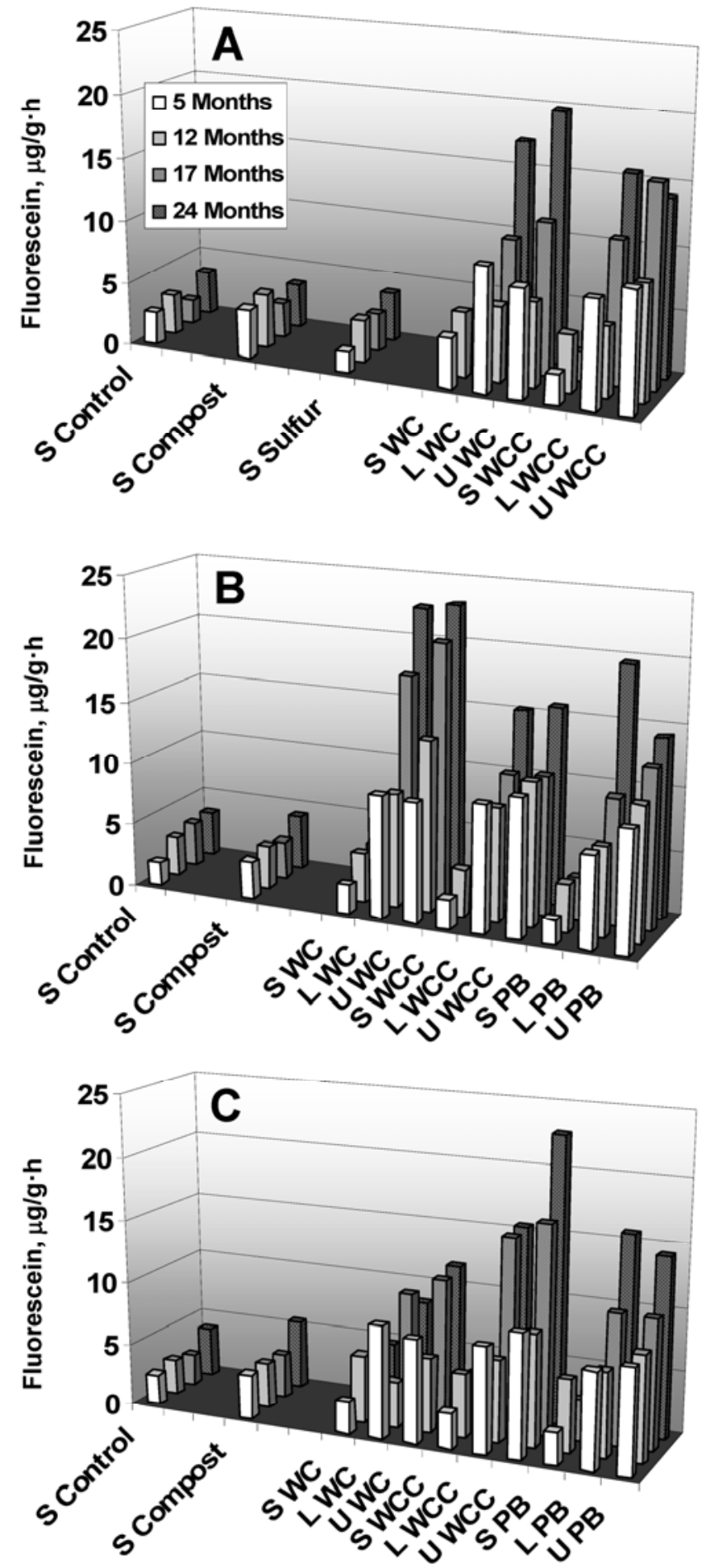

Fig. 4. Microbial activity by fluorescein diacetate hydrolysis (FDA) in soil and mulch samples from three Fraser fir study sites (A, Grayson; B, Avery-1; C, Watauga). Activity is reported as micrograms fluorescein released per gram dry sample, per hour. Treatments included nonamended control plots, compost or sulfur soil amendment, and wood chip (WC), wood chip with compost (WCC), or pine bark (PB) mulch, as raised beds. Sample types shown are soil (S), lower mulch (L), and upper mulch $(U)$. Mulch beds were established at time of planting, and samples were taken at $5,12,17$, and 24 months after planting. disease ratings at 1 year after planting $(r=0.655,0.736 ; P=0.008$, 0.002). After the first year, no further correlations with rainfall were observed. Soil moisture was significantly higher under mulch $(P<0.001)$, but tree survival at each time point did not covary with soil moisture $(P=0.309)$, nor was there a clear relationship be-
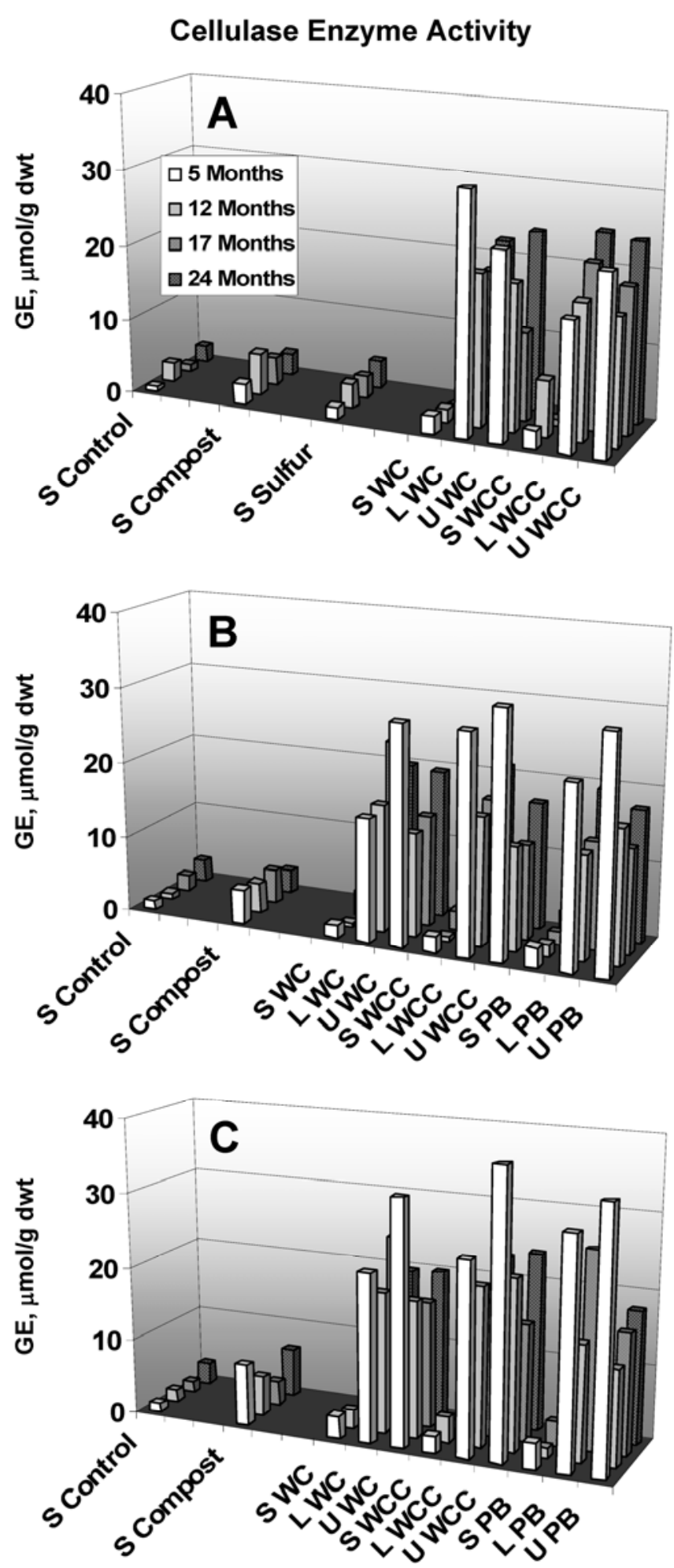

Fig. 5. Cellulase activity in soil and mulch samples from three Fraser fir study sites (A, Grayson; B, Avery-1; C, Watauga). Activity is reported as micromoles glucose equivalents (GE) released per gram dry sample after incubation with $0.35 \% \mathrm{CM}$ cellulose at $37^{\circ} \mathrm{C}$ for $24 \mathrm{~h}$. Treatments included nonamended control plots, compost or sulfur soil amendment, and wood chip (WC), wood chip with compost (WCC), or pine bark (PB) mulch, as raised beds. Sample types shown are soil (S), lower mulch (L), and upper mulch (U). Mulch beds were established at time of planting, and samples were taken at 5, 12, 17, and 24 months after planting. 
tween tree survival and moisture within the just upper portion of the root zone (soil or mulch).

\section{Discussion}

Organic mulch and compost based growing systems have met with mixed success for suppression of soilborne Phytophthora diseases in the field, with results ranging from significant suppression to enhancement of disease development $(11,13,17,34,36$, $49,50,55,56)$. Successful control has often been associated with the biological fraction of organic amendments $(16,18,32,58,59)$, and disease suppression has been demonstrated through reduced inoculum density (34), decreased disease incidence or severity $(13,50)$, and increased plant productivity $(17,55)$. Where organic amendments have been detrimental, these effects have been associated with increased moisture in the root zone, which favors zoospore production by Phytophthora species $(50,56)$. The relationship with moisture is complicated, however, because high moisture levels can also support larger populations of antagonistic microbes. In our trials with Fraser fir, mulches reduced disease ratings and mortality at three of five sites, while a single compost application tilled into soil did not impact disease ratings or mortality at any site. Disease suppression was related to microbial enzyme activity within the upper portion of the root zone, with a trend for total activity (FDA, nonsignificant at $\alpha=0.05$ ) and significant covariance with cellulase activity. Mulches did retain moisture and significantly increased the moisture content of underlying soils relative to unmulched soils, but there was no clear association between this increased moisture and changes in plant survival at each time point, supporting the premise of a dual role for moisture in both suppression and exacerbation of disease.

Biological analyses (plate counts on three media, FDA, and cellulase activity) were positively correlated to one another, but only the comparison of FDA and cellulase activity had a correlation coefficient above 0.50 . Enzyme analyses were generally more useful than plate counts for describing differences in biological activity among field samples, yielding clearer patterns in data and more significant differences among treatments. Plate counts on cellulose agar proved least valuable, with few significant differences among treatments and generally weak correlation to other analyses. This may be due in part to the presence in all samples of microorganisms capable of degrading cellulose in absence of other carbon sources, but which may not have contributed significantly to overall cellulase activity within the original sample. Dilution plating is often cited as under-representing total populations and over-representing subsets which can flourish on laboratory media, where both nutritional and competitive conditions are very different from those in the original sample (2). Although limited to a culturable subset of the population, these assays can be useful for tracking broad categories of organisms and substrate utilization potential. The differences in our results between counts on cellulose agar and cellulase activity suggest that all of our sample types served as reservoirs for organisms able to produce cellulase enzymes, but as expected, actual production of cellulase varied by sample type, reflecting differences in substrate availability. Differential treatment effects on bacterial versus fungal components of the microbial populations were also observed, particularly in the sulfur-treated soil. Dilution plating provided a relatively simple and inexpensive means of gauging diversity. Although the diversity indices derived from plates are limited by culture bias, richness from this subset is frequently as high as or higher than those derived from culture-independent methods, each of which has its own biases $(20,43)$. In this study, we observed higher microbial diversity in soils than in mulches, which is expected due to the high availability of a single substrate type in mulch, versus the higher microbial competition and niche diversification in soil (48). We did not find consistent differences in microbial diversity or disease suppression among mulch types, so we were unable to draw any conclusions as to the role of microbial diversity in disease suppression with mulches. Only one of the biological variables, cellulase activity, covaried significantly with tree survival. It is possible that clearer relationships may have been observed had we collected biological data at all five sites, especially given that differences in survival were recorded at three sites overall, but only at one of the three sites for which we have biological data.

Significant effects of mulch treatment were observed at the three sites with the highest overall mortality rates. Although limited data were collected on site factors in this study, general site descriptions suggest that site factors may have influenced levels of disease pressure across the sites. In natural stands of oak species, increased infection by $P$. cinnamomi has been associated with low soil fertility, particularly low phosphorus levels, and higher pathogen occurrence was also noted on south-facing aspects (40). The increased occurrence on south-facing slopes within the northern hemisphere may reflect soil temperature effects. These sites are likely to experience slightly warmer soil temperatures through the winter months, which may allow for better survival and increased activity of this pathogen, which appears to be geographically limited by cold temperatures and is most pathogenic in soil temperatures between 16 and $25^{\circ} \mathrm{C}(4,45,51,52)$. Although $P$. cinnamomi can be found in soils with a pH below 4, several studies have also noted that pathogen recovery and disease incidence from $P$. cinnamomi are less frequent in highly acidic soils $(40,51,52)$. In our study, two of the three highest-mortality sites had characteristics which might predict increased disease pressure, according to data from the distribution studies: the Mitchell site had the lowest humic matter and cation exchange capacity and the highest $\mathrm{pH}$ among the sites, and the Avery-2 site showed soil fertility problems with $\mathrm{P}$ and $\mathrm{Mn}$ deficiencies. The Watauga site, however, did not stand out as having characteristics which would predispose it to higher disease pressure, and the single south-facing site, Avery-1, was not among the highest-mortality sites.

The protection provided by mulches is dependent upon the suppressive microbial community resident in the much, and upon the balance among rates of root infection and deterioration and production of new healthy roots. For these systems to effectively manage root rot, roots within the mulch must be protected from new

Table 5. Plant tissue nutrient status of Fraser fir 17 months after site establishment ${ }^{2}$

\begin{tabular}{|c|c|c|c|c|c|c|}
\hline Nutrient & Control & Compost & Sulfur & PB mulch & WC mulch & WCC mulch \\
\hline $\mathrm{N}(\%)$ & $2.18 \mathrm{~b}$ & $2.09 \mathrm{~b}$ & $2.40 \mathrm{a}$ & $2.20 \mathrm{ab}$ & $2.19 \mathrm{~b}$ & $2.15 \mathrm{~b}$ \\
\hline $\mathrm{P}(\%)$ & $0.19 \mathrm{ab}$ & $0.21 \mathrm{~b}$ & $0.15 b$ & $0.23 \mathrm{ab}$ & $0.20 \mathrm{~b}$ & $0.27 \mathrm{a}$ \\
\hline $\mathrm{K}(\%)$ & $0.50 \mathrm{bc}$ & $0.48 \mathrm{bc}$ & $0.42 \mathrm{c}$ & $0.56 \mathrm{ab}$ & $0.51 b c$ & $0.59 \mathrm{a}$ \\
\hline $\mathrm{Ca}(\%)$ & 0.4 & 0.44 & 0.37 & 0.47 & 0.44 & 0.44 \\
\hline $\mathrm{Mg}(\%)$ & $0.11 \mathrm{a}$ & $0.13 \mathrm{ab}$ & $0.10 \mathrm{ab}$ & $0.08 \mathrm{~b}$ & $0.09 \mathrm{~b}$ & $0.10 \mathrm{ab}$ \\
\hline S (\%) & 0.12 & 0.13 & 0.16 & 0.13 & 0.13 & 0.14 \\
\hline $\mathrm{Fe}(\mathrm{ppm})$ & 65.2 & 71.8 & 89.7 & 67.9 & 69 & 72.2 \\
\hline $\mathrm{Mn}(\mathrm{ppm})$ & $177 \mathrm{~b}$ & $215 b$ & $932 \mathrm{a}$ & $538 \mathrm{ab}$ & $432 \mathrm{ab}$ & $285 \mathrm{ab}$ \\
\hline $\mathrm{Zn}(\mathrm{ppm})$ & 27.8 & 29.7 & 29.9 & 32.1 & 30.8 & 30.6 \\
\hline $\mathrm{Cu}(\mathrm{ppm})$ & 7.8 & 7.9 & 7.3 & 8.2 & 8.2 & 8.5 \\
\hline $\mathrm{B}(\mathrm{ppm})$ & $25.9 \mathrm{bc}$ & $24.3 \mathrm{abc}$ & $20.3 \mathrm{c}$ & $35.5 \mathrm{ab}$ & $29.4 a b c$ & $35.2 \mathrm{a}$ \\
\hline
\end{tabular}

${ }^{z}$ Values are means across five sites; means with the same letter within a row are not significantly different $(\alpha=0.05)$ using Tukey's HSD test. PB $=$ pine bark, $\mathrm{WC}=$ wood chip, $\mathrm{WCC}=$ wood chip with compost. 
infections, infections which occur within the soil must not progress to destroy roots within the mulch, and an adequate portion of the root system must lie within the mulch. The proportion of roots which must be maintained within the mulch will then depend upon the rates of infection and disease progression within the soil. In earlier studies conducted with avocado on a resistant rootstock, roots in the soil became infected with $P$. cinnamomi, but roots within mulch and at the soil-mulch interface remained relatively disease-free, and both total microbial activity (FDA) and cellulase activity were negatively correlated with Phytophthora inoculum potential (18). In the current study, high levels of total microbial activity and cellulase activity were achieved with all mulches, averaging 3.2 and 7.8 times higher, respectively, than levels within underlying soil. These ratios are not as high as those observed by Downer et al. (18), however, where mulches averaged 5.3 and 17.3 times higher FDA and cellulase activity, respectively, than soil. These differences may be due to variations in methods, but also may reflect differences in locally available mulch substrates. Although inoculum levels and root infection rates were not tracked over time in this study, changes in tree survival over time were significantly related to cellulase activity within the upper portion of the root zone (soil or mulch), suggesting that microbial cellulase production may have contributed to disease suppression. It is also likely that other organisms, aside from cellulase producers, may contribute to disease suppression within the mulch, even though the relationship between total microbial activity and tree survival was not significant in this study. In an evaluation of $P$. cinnamomi suppressive soil, McDonald et al. found no relationship between suppression and either total microbial activity or cellulase activity, bud did report that suppression was microbially mediated, with both general and specific types of suppression (38). While our work supports a role for cellulase activity in the suppression of Phytophthora root rot, measurement of enzyme activity provides a relatively coarse-resolution description of potential mechanisms, and it is likely that multiple types of suppression are acting simultaneously within any successful mulch-based system.

While all three mulch types sustained high microbial populations, activity, and cellulase production across all sites, our mulch systems failed to meet the criterion that roots within the mulch remain disease free. Within the small sample of trees analyzed in this study, infected roots were frequently found within lower mulch layers. As Fraser fir is highly susceptible to P. cinnamomi, this is likely due to the rapid progression of root colonization which initiated within soil and then expanded upward along individual roots. It is also possible that zoospores from soil may have been able to move into lower mulch during saturation events and initiate infection; however, similar mulches have previously been found to inhibit zoospore release and reduce the ability of zoospores to reach and infect host tissue (16). While further study could clarify which scenario is responsible for the occurrence of root infections within our mulches, either case suggests that development of resistant rootstocks will likely be required to limit the spread of Phytophthora and colonization of root systems. This work also suggests that some mulch substrates may encourage better root proliferation than others. As resistant root stocks and grafting techniques become available, further research is warranted to examine substrate selection and planting methods that encourage and sustain root growth within the mulch, as well as to minimize settling and wash-out of mulch and determine requirements for substrate replenishment.

While mulches provided significant suppression of Phytophthora root rot in field-planted Fraser fir at three of five sites, the level of protection was inconsistent across sites and inadequate as a stand-alone solution for growers. In the avocado system, mulching is also not recommended for use alone, but rather in conjunction with a set of cultural practices, including site preparation, irrigation management, and grafting with resistant root stocks. A combination of cultural controls and host resistance will likely be required to attain adequate control of Phytophthora root rot in Fraser fir. The disease suppression observed in this study indicates that mulches may be a valuable contribution to any future integrated management system.

\section{Acknowledgments}

We thank the North Carolina Agricultural Research Service and the North Carolina Christmas Tree Association for financial and logistical support, the North Carolina county agents and growers for their on-site assistance and the use of their land, and Laurence Madden, Ohio State University, for his invaluable statistical council.

\section{Literature Cited}

1. Adam, G., and Duncan, H. 2001. Development of a sensitive and rapid method for the measurement of total microbial activity using fluorescein diacetate (FDA) in a range of soils. Soil Biol. Biochem. 33:943-951.

2. Amann, R., Ludwig, W., and Schleifer, K. 1995. Phylogenetic identification and in situ detection of individual microbial cells without cultivation. Microbiol. Rev. 59:143-169.

3. Atlas, R. M. 2004. Handbook of Microbiological Media. CRC Press, Boca Raton, FL.

4. Balci, Y., Balci, S., Eggers, J., MacDonald, W. L., Juzwik, J., Long, R. P., and Gottschalk, K. W. 2007. Phytophthora spp. associated with forest soils in eastern and north-central U.S. oak ecosystems. Plant Dis. 91:705-710.

5. Beck, D. E. 1990. Abies fraseri (Pursh) Poir. Fraser fir. Pages 47-51 in: Silvics of North America: 1. Conifers. Agriculture Handbook 654. R. M. Burns and B. H. Honkala, eds. U.S. Dep. Agric. For. Serv.

6. Benson, D. M. 1984. Influence of pine bark, matric potential, and $\mathrm{pH}$ on sporangium production by Phytophthora cinnamomi. Phytopathology 74:1359-1363.

7. Benson, D. M., and Grand, L. F. 2000. Incidence of Phytophthora root rot of Fraser fir in North Carolina and sensitivity of isolates of Phytophthora cinnamomi to metalaxyl. Plant Dis. 84:661-664.

8. Benson, D. M., Grand, L. F., Vernia, C. S., and Gottwald, T. R. 2006. Temporal and spatial epidemiology of Phytophthora root rot in Fraser fir plantations. Plant Dis. 90:1171-1180.

9. Blaker, N. S., and Macdonald, J. D. 1983. Influence of container medium $\mathrm{pH}$ on sporangium formation, zoospore release, and infection of rhododendron by Phytophthora cinnamomi. Plant Dis. 67:259-263.

10. Broadbent, P., and Baker, K. F. 1974. Behaviour of Phytophthora cinnamomi in soils suppressive and conducive to root rot. Aust. J. Agric. Res. 25:121-137.

11. Bryla, D. R., Linderman, R. G., and Yang, W. Q. 2008. Incidence of Phytophthora and Pythium infection and the relation to cultural conditions in commercial blueberry fields. HortScience 43:260-263.

12. Bulluck, R., Shiel, P., Berger, P., Kaplan, D., Parra, G., Li, W., Levy, L., Keller, J., Reddy, M., Sharma, N., Dennis, M., Stack, J., Pierzynski, J., O'Mara, J., Webb, C., Finley, L., Lamour, K., McKemy, J., and Palm, M. 2006. A comparative analysis of detection techniques used in US regulatory programs to determine presence of Phytophthora ramorum in Camellia japonica 'Nucio's Gem' in an infested nursery in Southern California. Online. Plant Health Progress doi:10.1094/PHP-2006-1016-01-RS.

13. Chellemi, D. O. 2006. Effect of urban plant debris and soil management practices on plant parasitic nematodes, Phytophthora blight and Pythium root rot of bell pepper. Crop Prot. 25:1109-1116.

14. Cook, R. J., and Baker, K. F. 1983. The Nature and Practice of Biological Control of Plant Pathogens. American Phytopathological Society, St. Paul, $\mathrm{MN}$

15. Cordell, C. E., and Astin, J. S., Jr. 1965. A new host for Fomes annosus, Polyporus schweinitzii and Fomes pini. Plant Dis. Rep. 49:360.

16. Costa, J. L. D., Menge, J. A., and Casale, W. L. 1996. Investigations on some of the mechanisms by which bioenhanced mulches can suppress Phytophthora root rot of avocado. Microbiol. Res. 151:183-192.

17. Downer, A. J., Menge, J. A., Ohr, H. D., Faber, B. A., McKee, B. S., Pond, E. G., Crowley, M. G., and Campbell, S. D. 1999. The effect of yard trimmings as a mulch on growth of avocado and avocado root rot caused by Phytophthora cinnamomi. Calif. Avocado Soc. Yearb. 83:87-104.

18. Downer, A. J., Menge, J. A., and Pond, E. 2001. Association of cellulytic enzyme activities in eucalyptus mulches with biological control of Phytophthora cinnamomi. Phytopathology 91:847-855.

19. Downer, J., Faber, B., and Menge, J. A. 2002. Factors affecting root rot control in mulched avocado. HortTechnology 12:601-605.

20. Edenborn, S. L., and Sexstone, A. J. 2007. DGGE fingerprinting of culturable soil bacterial communities complements culture-independent analyses. Soil Biol. Biochem. 39:1570-1579.

21. Farr, D. F., Rossman, A. Y., Palm, M. E., and McCray, E. B., n. d. 2005 Fungal Databases, Systematic Botany and Mycology Laboratory, U.S. Dep. Agric. ARS. Online publication. Retrieved 20 Nov. 2010.

22. Ferguson, A. J., and Jeffers, S. N. 1999. Detecting multiple species of Phytophthora in container mixes from ornamental crop nurseries. Plant Dis. 83:1129-1136.

23. Frampton, J., and Benson, D. M. 2004. Phytophthora root rot mortality in Fraser fir seedlings. HortScience 39:1025-1026.

24. Grand, L. F., ed. 1985. North Carolina Plant Disease Index. 2nd ed. Tech Bull. 240. N.C. Agric. Res. Serv., North Carolina State University, Raleigh. 
25. Grand, L. F., and Lapp, N. A. 1974. Phytophthora cinnamomi root rot of Fraser fir in North Carolina. Plant Dis. Rep. 58:318-320.

26. Hill, T. C. J., Walsh, K. A., Harris, J. A., and Moffett, B. F. 2003. Using ecological diversity measures with bacterial communities. FEMS Microbiol. Ecol. 43:1-11.

27. Hinesley, E., and Frampton, J. 2002. Grafting Fraser fir onto rootstocks of selected Abies species. HortScience 37:815-818.

28. Hinesley, L. E., Parker, K. C., and Benson, D. M. 2000. Evaluation of seedlings of Fraser, Momi, and Siberian fir for resistance to Phytophthora cinnamomi. HortScience 35:87-88.

29. Huberli, D., Tommerup, I. C., and Hardy, G. E. St. J. 2000. False-negative isolations or absence of lesions may cause mis-diagnosis of diseased plants infected with Phytophthora cinnamomi. Australas. Plant Pathol. 29:164169.

30. Jeffers, S. N., and Martin, S. B. 1986. Comparison of two media selective for Phytophthora and Pythium species. Plant Dis. 70:1038-1043.

31. Juneau, P. 2007. Nonparametric Methods in Pharmaceutical Statistics. Pages 117-149 in: Pharmaceutical Statistics Using SAS ®: A Practical Guide. A. Dmitrienko, C. Chuang-Stein, and R. D. D'Agostino, eds. SAS Press series. SAS Institute, Cary, NC.

32. Kim, K. D., Nemec, S., and Musson, G. 1997. Effects of composts and soil amendments on soil microflora and Phytophthora root and crown rot of bell pepper. Crop Prot. 16:165-172.

33. Ko, W. H., and Shiroma, S. S. 1989. Distribution of Phytophthora cinnamomi-suppressive soil in nature. J. Phytopathol. 127:75-80.

34. Konam, J. K., and Guest, D. I. 2002. Leaf litter mulch reduces the survival of Phytophthora palmivora under cocoa trees in Papua New Guinea. Australas. Plant Pathol. 31:381-383.

35. Kox, L. F. F., van Brouwershaven, I. R., van de Vossenberg, B. T. L. H., van den Beld, H. E., Bonants, P. J. M., and de Gruyter, J. 2007. Diagnostic values and utility of immunological, morphological, and molecular methods for in planta detection of Phytophthora ramorum. Phytopathology 97:11191129.

36. Liu, B., Gumpertz, M. L., Hu, S. J., and Ristaino, J. B. 2008. Effect of prior tillage and soil fertility amendments on dispersal of Phytophthora capsici and infection of pepper. Eur. J. Plant Pathol. 120:273-287.

37. Magurran, A. E. 1988. Ecological Diversity and Its Measurement. Princeton University Press, Princeton, NJ.

38. McDonald, V., Pond, E., Crowley, M., McKee, B., and Menge, J. 2007. Selection for and evaluation of an avocado orchard soil microbially suppressive to Phytophthora cinnamomi. Plant Soil 299:17-28.

39. McDougall, K. L., Hardy, G. E. St. J., and Hobbs, R. J. 2002. Distribution of Phytophthora cinnamomi in the northern jarrah (Eucalyptus marginata) forest of Western Australia in relation to dieback age and topography. Aust. J. Bot. 50:107-114

40. Moreira, A. C., and Martins, J. M. S. 2005. Influence of site factors on the impact of Phytophthora cinnamomi in cork oak stands in Portugal. For. Pathol. 35:145-162.

41. O'Brien, P., Williams, N., and Hardy, G. E. St. J. 2009. Detecting Phytophthora. Crit. Rev. Microbiol. 35:169-181.

42. Pegg, K. G. 1977. Soil application of elemental sulphur as a control of Phytophthora cinnamomi root and heart rot of pineapple. Aust. J. Exp. Agric. Anim. Husb. 17:859-865.

43. Ranjard, L., Poly, F., and Nazaret, S. 2000. Monitoring complex bacterial communities using culture-independent molecular techniques: Application to soil environment. Res. Microbiol. 151:167-177.

44. Shew, H. D., and Benson, D. M. 1982. Qualitative and quantitative soil assays for Phytophthora cinnamomi. Phytopathology 72:1029-1032.

45. Shew, H. D., and Benson, D. M. 1983. Influence of soil temperature and inoculum density of Phytophthora cinnamomi on root rot of Fraser fir. Plant Dis. 67:522-524.

46. Shi, W., Dell, E., Bowman, D., and Iyyemperumal, K. 2006. Soil enzyme activities and organic matter composition in a turfgrass chronosequence. Plant Soil 288:285-296.

47. Tsao, P. H. 1964. Effect of certain fungal isolation agar media on Thielaviopsis basicola and on its recovery in soil dilution plates. Phytopathology 54:548-555.

48. van Bruggen, A. H. C., and Semenov, A. M. 2000. In search of biological indicators for soil health and disease suppression. Appl. Soil Ecol. 15:13 24.

49. Vawdrey, L. L., Grice, K. E., Peterson, R. A., and De Faveri, J. 2004. The use of metalaxyl and potassium phosphonate, mounds, and organic and plastic mulches, for the management of Phytophthora root rot of papaya in far northern Queensland. Australas. Plant Pathol. 33:103-107.

50. Vawdrey, L. L., Martin, T. M., and De Faveri, J. 2002. The potential of organic and inorganic soil amendments, and a biological control agent (Trichoderma sp.) for the management of Phytophthora root rot of papaw in far northern Queensland. Australas. Plant Pathol. 31:391-399.

51. Vettraino, A. M., Barzanti, G. P., Bianco, M. C., Ragazzi, A., Capretti, P., Paolettti, E., Luisi, N., Anselmi, N., and Vannini, A. 2002. Occurrence of Phytophthora species in oak stands in Italy and their association with declining oak trees. For. Pathol. 32:19-28.

52. Vettraino, A. M., Morel, O., Perlerou, C., Robin, C., Diamandis, S., and Vannini, A. 2005. Occurrence and distribution of Phytophthora species in European chestnut stands, and their association with Ink Disease and crown decline. Eur. J. Plant Pathol. 111:169-180.

53. Vettraino, A. M., Sukno, S., Vannini, A. and Garbelotto, M. 2010. Diagnostic sensitivity and specificity of different methods used by two laboratories for the detection of Phytophthora ramorum on multiple natural hosts. Plant Pathol. 59:289-300.

54. von Mersi, W., and Schinner, F. 1996. CM-cellulase activity. Pages 190-193 in: Methods in Soil Biology. F. Schinner, R. Öhlinger, E. Kandeler, and R. Margesin, eds. Springer-Verlag, Berlin.

55. Widmer, T. L., Graham, J. H., and Mitchell, D. J. 1999. Composted municipal solid wastes promote growth of young citrus trees infested with Phytophthora nicotianae. Compost Sci. Util. 7:6-16.

56. Wilcox, W. F., Pritts, M. P., and Kelly, M. J. 1999. Integrated control of Phytophthora root rot of red raspberry. Plant Dis. 83:1149-1154.

57. Williams, R., Glenn, W., Hayes, C., and Neas, K. 2002. Evaluation of the Competitive Position of the Fraser Fir Christmas Tree. U.S. Dep. Agric. Agric. Marketing Serv. Online report.

58. You, M. P., and Sivasithamparam, K. 1994. Hydrolysis of fluorescein diacetate in an avocado plantation mulch suppressive to Phytophthora cinnamomi and its relationship with certain biotic and abiotic factors. Soil Biol. Biochem. 26:1355-1361.

59. You, M. P., and Sivasithamparam, K. 1995. Changes in microbial populations of an avocado plantation mulch suppressive of Phytophthora cinnamomi. Appl. Soil Ecol. 2:33-43.

60. Zentmyer, G. A. 1971-1972. Avocado Root Rot. Calif. Avocado Soc. Yearb. $55: 29-36$ 